\title{
Mechanical Properties of Human Acetabulum
}

by

\author{
Yoshio Shirasaki, Tetsuya TAteishi*1, and Yutaka MiYanagA*2 \\ ${ }^{* 1}$ Mechanical Engineering Laboratory, Namiki 1, Sakuramura, \\ Ibaraki 305 \\ *2 Faculty of Medicine, University of Tokyo, Hongo 7-3-1, \\ Bunkyo-ku, Tokyo
}

Mechanical properties of the various regions of cancellous bone and cartilage-cancellous bone composite of the human acetabulum were investigated.

Their elastic moduli and strengtns were almost the same as those of the femoral head, while their phase lags were lower than those of the femoral head.

Their regional difference of the mechanical properties was not so much as in the femoral head. This fact was considered to depend on the difference of the loading condition between the acetabulum and the femoral head.

Dynamic behavior of the acetabulum was also studied by a compression test.

\section{寛骨白蓋部の力学特性}

\author{
白 崎 芳夫・立石哲 也蓉 永 豊 ${ }^{* 2}$
}

（原稿受理：1982年 2 月 2 日）

\section{1. は じめに}

股関節は球関節を形成し, その形状や内部構造は種々の疾患に よって変化することが知られている. 例えば, 変形性股関節症に 招いては球状に近い大腿骨骨頭 (Femoral head) の形状が扁平し たり，疾患が進すると骨頭内部にシスト (Cyst) とよばれる大小 の空洞の発生が観察される.このよ5な変形性関節症の力学的原 因を究明するために, 著者らは正常および変形性関節症の大腿骨 骨頭各部位から切り出した海綿骨, 軟骨・海綿骨複合系の試料を 用いて, 両者の静的強度执よび粘弾性特性を測定し, その差異を 定量的に明らかにした ${ }^{1), 2)}$.

股関節の力学特性に関する研究は, 主に大腿骨骨頭側に限られ た感があり寛骨臼蓋部 (Acetabulum) については, 従来あまり 注目されていなかった ${ }^{3), 4)}$. しかし, 股関節は大腿骨骨頭と寛骨 臼蓋で構成され, 股関節の力学特性を明らかにするためには寛骨

*1 機械技術研究所 $=300-31$ 茨城県新治郡桜村並木 $1-2$

*2 東京大学医学部整形外科学教室 $=113$ 東京都文京区本郷 7-3-1
臼蓋部の力学特性を明らかにする必要がある。

本報告では正常な宽骨曰蓋部から採取した海綿骨, 軟骨・海綿 骨複合系の試料を用いて粘弾性特性, 静的強度を測定したので, その結果について述べる。

\section{2. 試料および実験方法}

本実験に用いた寛骨臼蓋部（以下，臼蓋と記す）は，2個体い ずれも男性で 59 才， 62 才である. 股関節 (Hip joint) 各部の学 術名をFig. 1 亿示寸. 試料の保存は冷涷で扣こなった。 日蓋か らの試験片採取位置は Fig. 2, Fig. 3 の○印で示す. 試験片形 状は直径 $6.3 \mathrm{~mm}$, 軟骨・海綿骨複合系は長さ $10.0 \mathrm{~mm}$ 程度, 海 綿骨は長さ $8.0 \mathrm{~mm}$ 程度の円筒形である.

粘弾性測定には高出力型粘弾性スペクトロメータを用い, 周波 数 $10 \mathrm{~Hz}$, 静的圧力 $26.0 \times 10^{-2} \mathrm{MPa}$, 動的応力振幅 $19.0 \times 10^{-2} \mathrm{MPa}$ で測定した。静的圧縮試験は TOM500を用い, クロスヘッドス ピード $3 \mathrm{~mm} / \mathrm{min} て ゙$ でなった。 な扔, 実験中は試料の乾燥を防 ぐために生理食塩水を点滴した。 


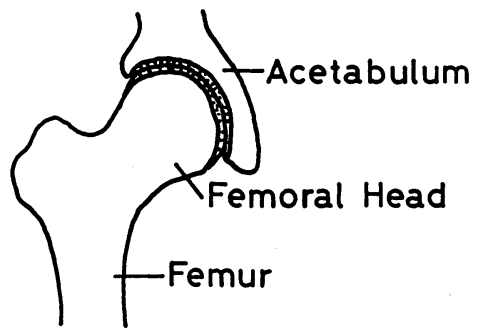

Hip Joint

Fig. 1 Schematic representation of human hip joint.

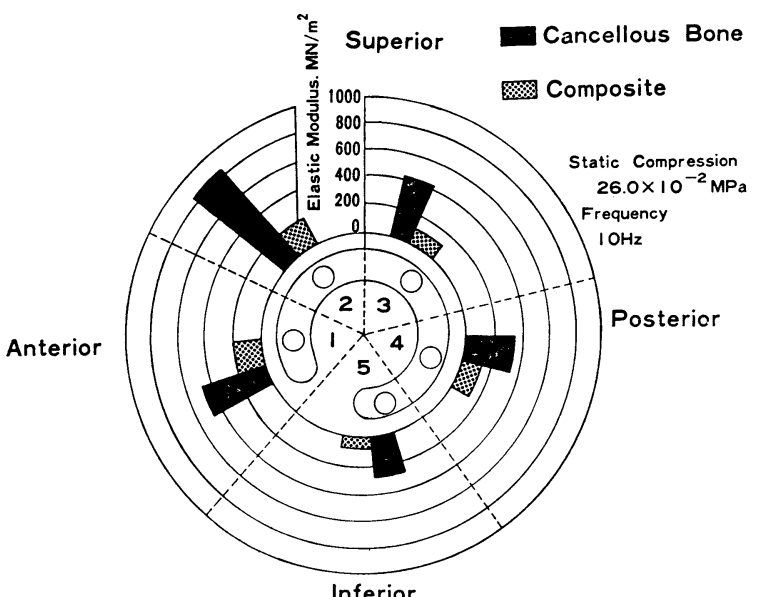

Fig. 2 Regional difference ef elastic modulus of cancellous bone and cartilage-cancellous bone composite.

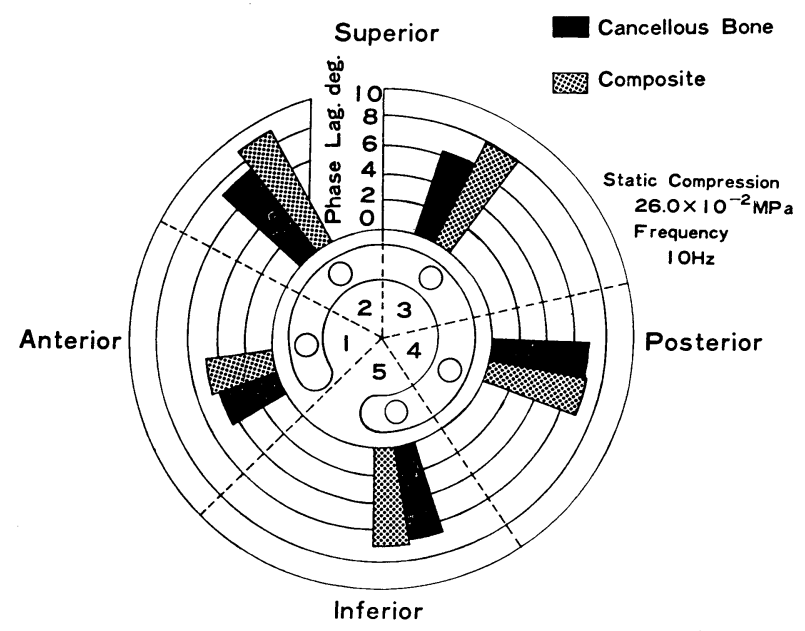

Fig. 3 Regional difference of phase lag of cancellous bone and cartilage-cancellous bone composite.

\section{3. 実験結果および考察}

Fig. 2 は田蓋各部位に拈ける海綿骨 (Cancellous bone) 执よ び軟骨・海綿骨複合系 (Composite) の動的弾性率の值を示す. 海綿骨の弾性率の值を各部位別に整理してみると, 部位 1 から順 に $536 \mathrm{MN} / \mathrm{m}^{2}, 829 \mathrm{MN} / \mathrm{m}^{2}, 463 \mathrm{MN} / \mathrm{m}^{2}, 350 \mathrm{MN} / \mathrm{m}^{2}, 305 \mathrm{MN} / \mathrm{m}^{2}$ の值であり, 部位 2 が最も高い值を示している。これは, 股関節 に作用する力は Rydell の生体計測によると, 両脚拉よび片脚立
ちでも前上外方から作用し ${ }^{5)}$ ，その值は Paul の計測によると歩 行の立脚期で体重の 3.3 倍, 片脚立ちで 2.6 倍, 走行時 4 . 倍の值 になっている ${ }^{6)}$ 。したがって，通常の場合では上記の結果から部 位 2 が最大荷重部となる。これは, 大腿骨骨頭（以下，骨頭と記 す）各部位から切り出した海綿骨の動的弾性率についても同様な ことが言える。事実，骨頭に执いて弾性率の值が最も高い部位は 前部 (Anterior) がある。この部位は田蓋側では部位 2 に相当す る.弾性率の值は骨頭前部に比較して低くなっている，他の対応 する部位についても同様な傾向を示し，且蓋側の海綿骨は骨頭側 のそれより弾性率の值が若干低くなっている，軟骨・海綿骨複合 系では，弾性率には海綿骨程著しい差はない。これは，関節軟骨 の主要なはたらさの一つである荷重分散機構7)により複合系に作 用する集中荷重を分散させているためである.

Fig. 3は海綿骨および軟骨・海綿骨複合系の各部位における内 部減衰の值を示す．海綿骨と複合系の值を比較してみると，複合 系の值は軟骨の影響を受けて海綿骨より高い值を示している．部 位別では 2 の值が海綿骨, 複合系ともに他の部位に比較して高く なっている。これは，この部位では大きな外荷重を支持しなくて はならない，そのため，結果的には骨密度の増加ないしは硬化を きたし，弾性率の值が高くなっている，内部減衰の值が高いとい うことについては，以下のような解釈ができる。一般に弾性率は 材料の強度に関係し, 内部減衰は材料の勒性に関係するといわれ ている. したがって, 部位 2 の海綿骨は他の部位に比較して荷重 支持性およびダンピング効果が大きい材料である.
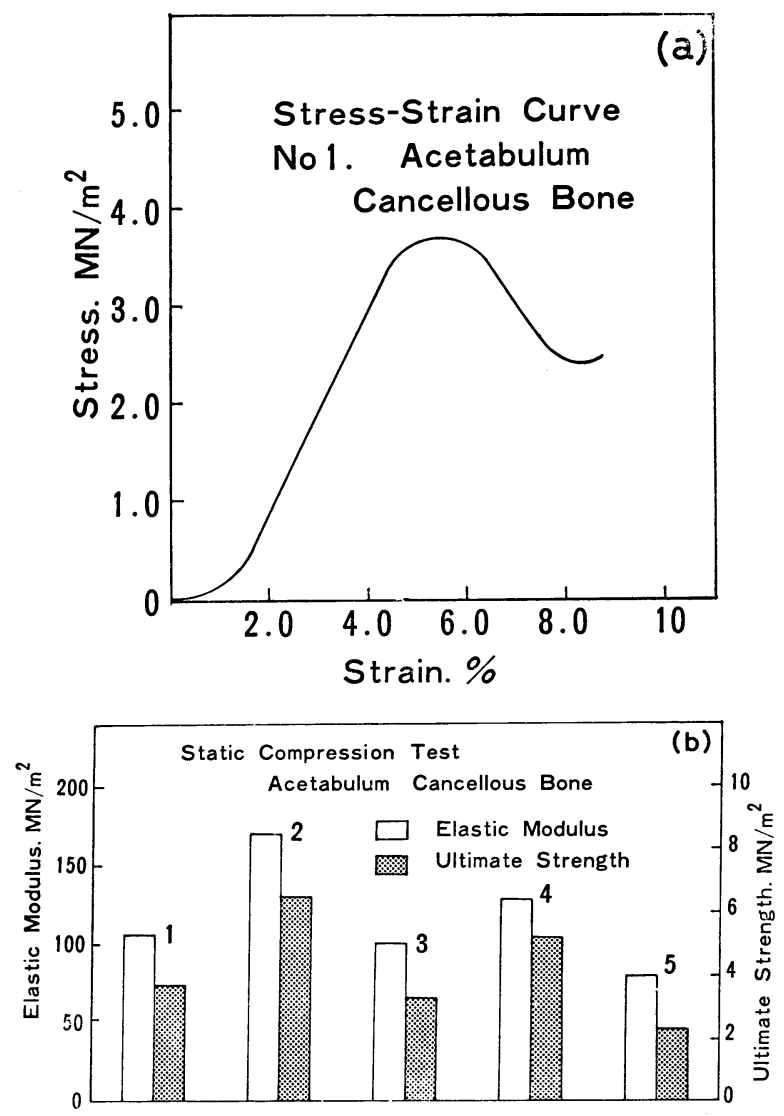

Fig. 4 Examples of (a) stress-strain curve of an acetabulum and (b) the rseults of a static compression test. 
Fig. 4 は静的圧縮試験に搞ける応力ーひずみ曲線と各部位の静 的弾性率 (応力ーひずみ曲線の直線部分の傾きを静的弾性率と定 義する）扣よび圧縮強度を示す。弾性率の值については部位 2 が 最も高く， 4, 1, 3, 5 の順に低下している. 圧縮強度の值につ いても弾性率の傾向と一致している.

これらの力学特性と病理学との関係については, 東らの目蓋部 の経年変化に関する研究がある ${ }^{8)}$. この研究では日蓋部の変化と 年令との相関をしらべている。 その結果によると，加龄にしたが って目蓋の変化は顕著かつ広範ななる傾向があり, 変化が早期に 強くあらわれる部位は田蓋の前上方部, すなわち部位 2 飞相当す る. 比較的変化が少ない部位は下方部 (5)であることを報告し， 荷重頻度技よび荷重支持性が高い部位が早期に破綻がくることを 示唆している.

股関節の運動機能および力学的適合性を考える場合, 且蓋にお ける荷重負荷部分あるいは大腿骨頭との接触部分の正確な位置を 知ることは重要である。これに関して，Greenwald らはヒト股関 節を用いて負荷運動時に拈ける接触部位をいろいろの方から荷 重を負荷し，染色法によって関節面の負荷部位と接触面積を求め ている ${ }^{9)}$.この結果によれば, 歩行の立脚時では臼蓋の全関節面 が体重負荷に関与している。このとさ，大腿骨頭関節面において は骨頭召周囲から下部にかけて帯状の非接触部がある。荷重が少 ない場合には曰蓋全関節面の接触状態から部分接触となり，目蓋 上方部がドーム状の非接触部分になっている。また，著者の一人 である宮永らの研究によると ${ }^{10)}$, 接触部位と接触圧の大きさや分 布は荷重量に依存し， 日蓋では接触圧は前部と後部を中心に分布 している. 田蓋頂点では低い值を示している。 また, 荷重量の増 加とともに接触圧も大きくなり, 面積も增加している。この最大 接触圧を示す位置は部位 2 亿相当している。 これらの事実は, 海 綿骨拉よび軟骨の力学特性の合理的な組み合せによって, 関節に お㚈る荷重支持, 荷重伝達機構の適合性をよくし, 関節の合目的 な構造を示するのである。

\section{4. む す び}

股関節の力学特性の研究に括いて，従来あまり注目されていな かった䨘骨臼蓋各部位より切り出した海綿骨, 軟骨・海綿骨複合 系の試料を用いて, 粘弾性特性および静的強度を測定した。 この 結果は股関節の接触圧の分布状態掞よび荷重頻度, 荷重支持性が 高い部位が早期に破綻がくることを示唆する病理学的な所見と一 致している. しかし, さらに試料の数を增し信頼性の高いデータ を蓄積し, 力学特性ばかりではなく, 内部構造との関連や加龄に よる変化を詳細に検討していくことが今後の研究課題である.

\section{文献}

1）立石哲也，白崎芳夫，宮永豊，日本機械学会論文集，44, 3425 (1978).

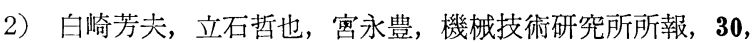
32 (1976).

3) Evans, F.G., “Mechanical Properties of Bone.”, p. 211 (1973) ; C.C. Thomas. Illinois.

4) Freeman, M.A.R., “Adult Articular Cartilage.”, p. 178 (1973) ; Grune \& Stratton, New York.

5) Rydell, M.W., Acta Orthop. Scand., 37, Suppl. 88 (1966).

6) Paul, J.P., Proc. Inst. Mech. Eng., 182, part 3 J : 8-15 (1967).

7）城田康平, 立石哲也, 白崎芳夫, 宮永豊, 日本機械学会講 演論文集, No. 790-2, 189 (1979).

8）東博彦，ほか 5 名, Hip Joint., 3, 94 (1977).

9) Greenwald, A.S., and Haynes, D.W., J. Bone Joint Surg., 54B, 157 (1972).

10）宫永豊, 福林徽, 臨床整形外科, 14-11，1096 (1979). 